\title{
KAJIAN KINERJA PERSIMPANGAN TIDAK BERSINYAL (STUDI KASUS : PERSIMPANGAN TIGA GADUT, JALAN RAYA INDARUNG - BANDAR BUAT, KOTA PADANG)
}

\author{
Eko Prayitno ${ }^{1}$ Veronika $^{2}$ \\ Prodi Teknik Sipil, Fakultas Teknik Sipil dan Perencanaan Universitas Bung Hatta ${ }^{1,2}$ \\ ekoprayitno@bunghatta.ac.id ${ }^{1}$, veronika@bunghatta.ac.id ${ }^{2}$
}

DOI: http://dx.doi.org/10.31869/rtj.v2i2.1183

\begin{abstract}
The highway is one of the infrastructure for the smooth traffic. One part of the road that are considered necessary to be analyzed and evaluated is an intersection. Three Gadut intersection is non signalized intersection. The traffic flow is quite dense, and lack of discipline of road user factors competing space to pass the crossing, resulting in congestion is very influential on traffic conditions at peak hours in the morning, afternoon and evening. Prior to conducting the survey, the first to do is survey the condition of the intersection that includes geometric characteristics and traffic volume. From the analysis of environmental data, side friction factor to the junction of three Gadut is the criteria being. Rated capacity $(C)$ the smallest is 3706.3 smp/hour, the degree of saturation of 1.1 smp/hour. This value is over the limit permitted values manually indonesian road capacity of 0.8 to $0.9(1.1>0.9)$, it is concluded that the traffic flow is the crossroads of three Gadut saturated traffic flow. The queue probability value between $128.8 \%$ - $157.4 \%$ with a total delay largest average 11.57 seconds/smp. It is concluded that the chances of a queue at the intersection of three Gadut very large, so it could cause congestion.
\end{abstract}

Keywords : Roads, Intersections, Traffic, Congestion

Abstrak: Jalan raya merupakan salah satu prasarana bagi kelancaran lalu-lintas. Salah satu bagian dari jalan raya yang dianggap perlu untuk dianalisa serta dievaluasi adalah persimpangan. Persimpangan tiga gadut adalah persimpangan tidak bersinyal. Arus lalu lintasnya cukup padat, serta kurangnya faktor disiplin dari pemakai jalan yang saling berebut ruang untuk melewati persimpangan sehingga mengakibatkan kemacetan yang sangat berpengaruh pada kondisi lalu lintas pada jam puncak pagi, siang dan sore. Sebelum dilakukan survai lalu lintas, pertama yang dilakukan adalah survai kondisi persimpangan yang meliputi geometrik, karakteristik dan volume lalu lintas. Dari hasil analisis data lingkungan, faktor hambatan samping untuk persimpangan tiga gadut adalah kriteria sedang. Nilai kapasitas (C) yang terkecil adalah 3706,3 smp/jam, nilai derajat kejenuhan sebesar 1,1 smp/jam. Nilai ini sudah melewati batas nilai yang diijinkan manual kapasitas jalan indonesia sebesar $0,8-0,9(1,1>0,9)$, hal ini disimpulkan bahwa arus lalu lintas dipersimpangan tiga gadut adalah arus lalu lintas jenuh. Nilai peluang antrian terbesar antara 128,8 \% - 157,4 \% dengan tundaan total ratarata terbesar 11,57 detik/smp. Hal ini disimpulkan bahwa peluang antrian pada persimpangan tiga gadut sangat besar, sehingga bisa menyebabkan kemacetan.

Kata kunci : Jalan raya, Persimpangan, Lalu lintas, Kemacetan

\section{PENDAHULUAN}

Jalan raya merupakan salah satu prasarana bagi kelancaran lalu-lintas. Semakin pesatnya pembangunan suatu daerah atau kota, maka semakin ramai lalu-lintasnya. Hal ini disebabkan karena meningkatnya pendapatan penduduk sehingga mampu mempunyai kendaraan sendiri. Karena semakin meningkatnya jumlah kendaraan dijalan raya akan menimbulkan kemacetan lalu lintas yang dapat mempengaruhi kualitas dari pelayanan jalan tersebut. Kemacetan serta kesibukkan lalu lintas itu sering terjadi pada ruas jalan atau persimpangan jalan, terutama pada pagi, siang maupun sore.

Salah satu bagian dari jalan raya yang dianggap perlu untuk dikaji adalah persimpangan. Persimpangan terdiri dari dua jenis, yaitu, persimpangan bersinyal dan persimpangan tidak bersinyal. Persimpangan 
bersinyal adalah persimpangan yang memiliki rambu lampu lalu lintas, sedangkan persimpangan tidak bersinyal, tidak memiliki rambu lampu lalu lintas (Peraturan Menteri Perhubungan, 2006).

Tingkat mobilitas masyarakat kota Padang paling tinggi dilingkup Sumatera Barat, karena selain ibu kota Propinsi, kota Padang juga sebagai pusat perdagangan, industri dan pendidikkan. Akibatnya kebutuhan pelayanan jasa transportasi semakin meningkat setiap tahun yang dapat dilihat dari meningkatnya epemilikkan kendaraan bermotor yang tidak sebanding dengan pertumbuhan penyediaan sarana transportasi (Anisa, 2009).

Persimpangan tiga gadut adalah persimpangan tidak bersinyal. Arus lalu lintasnya cukup padat, serta kurangnya faktor disiplin dari pemakai jalan yang saling berebut ruang untuk melewati persimpangan sehingga mengakibatkan adanya kemacetan yang sangat berpengaruh pada kondisi lalu lintas pada jam puncak yaitu pada pagi hari, siang hari, dan sore hari.

Berdasarkan latar belakang tersebut, dirumuskan tujuan penelitian ini :

1. Mengkaji kelayakkan persimpangan tidak bersinyal dipersimpangan tiga gadut, jalan raya indarung - bandar buat, kota Padang.

2. Mengetahui pengaruh kemacetan dipersimpangan tidak bersinyal berdasarkan volume lalu lintas, kapasitas, derajat kejenuhan, tundaan total rata-rata dan peluang antrian.

\section{TINJAUAN PUSTAKA \\ Klasifikasi Jalan Raya}

Jalan raya adalah salah satu prasarana bagi kelancaran lalu-lintas baik disuatu kota maupun pedesaan atau daerah lainnya, semakin pesatnya pembangunan suatu daerah atau kota semakin ramai pula lalu-lintasnya (Sukirman Silvia, 1994). Kemacetan serta kesibukan lalu lintas itu sering terjadi pada ruas jalan atau persimpangan jalan, terutama pada pagi hari maupun sore hari dimana para pelajar, mahasiswa, pekerja, serta pedagang menuju tempat aktivitasnya masing-masing (Oglesby, Clarkson H, 1995).

Salah satu bagian dari jalan raya yang dianggap perlu untuk dianalisa serta dievaluasi adalah persimpangan. Analisa kapasitas dan evaluasi pada persimpangan merupakan hal yang penting dalam menilai karakteristik dan seberapa besar tingkat pelayanan dari persimpangan tersebut (Manual Kapasitas Jalan Indonesia, 1997). Sebab tingkat pelayanan pada suatu persimpangan memberikan efek yang signifikan dalam pengoperasian secara keseluruhan lalu lintas dipersimpangan tersebut.

\section{Persimpangan Jalan}

Persimpangan merupakan suatu daerah yang cukup rawan untuk terjadinya konflik lalu lintas yang mengakibatkan terjadinya kecelakaan sesama kendaraan maupun kendaraan dengan pejalan kaki. Titik konflik dan jenis manufer pada setiap persimpangan berdasarkan Manual Kapasitas Jalan Indonesia (Manual Kapasitas Jalan Indonesia, 1997) dapat dilihat pada gambar 1. berikut ini :
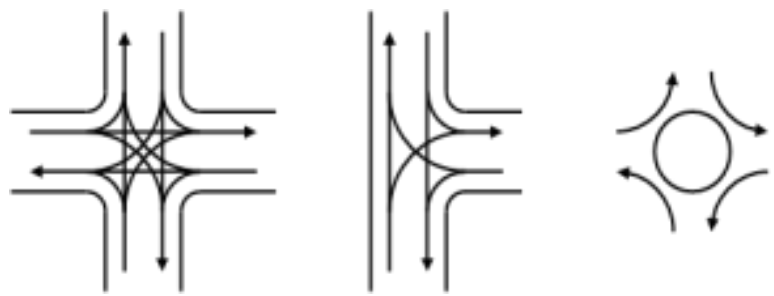

Gambar 1. Potensi titik konflik pada persimpangan

Sumber : Manual Kapasitas Jalan Indonesia, 1997

\section{Persimpangan Tidak Bersinyal}

Terdapat beberapa persimpangan tak bersinyal, semua jenis persimpangan dianggap krep dan trotoar yang sesuai dan ditempatkan pada daerah dengan hambatan samping, gambar jenis-jenis persimpangan tiga lengan dapat dilihat pada gambar 2. berikut ini :
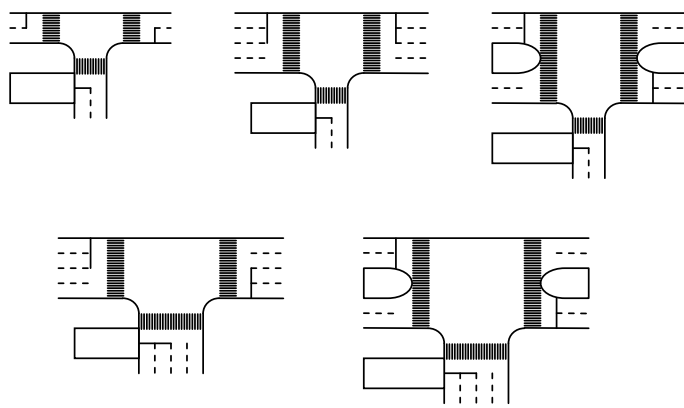

Gambar 2. Jenis-jenis persimpangan tiga lengan

Sumber : Manual Kapasitas Jalan Indonesia, 1997

$202 \quad$ Fakultas Teknik UMSB

ISSN 2599-2081

EISSN 2599-2090 


\section{Karakteristik Kendaraan}

Dalam berlalu lintas terdapat berbagai jenis kendaraan yang masing-masing mempunyai ciri tersendiri dengan perbedaan seperti dimensi, berat, kapasitas angkut, tenaga penggerak, karakteristik pengendalian yang sangat berpengaruh dalam operasi lalu lintas (Khisty, C, Jotin dan Lall, B, Kent, 2005). Pada studi ini jenis kendaraan yang teliti dikelompokkan dalam 4 (empat) jenis dengan karakteristik dan defenisi sebagai berikut (Pedoman Pengumpulan Data Lalu Lintas, 1990):

1. Kendaraan ringan (LV)

Kendaraan bermotor ber-as dua dengan 4 roda dan dengan jarak as 2,0 - 3,0 m (meliputi : mobil penumpang, oplet, mikrobis dan truk kecil sesuai dengan sistem klasifikasi bina marga)

2. Kendaraan berat (HV)

Kendaraan bermotor dengan 4 roda lebih (meliputi : bus, truk 2as, truk 3as dan truk kombinasi sesuai dengan sistem klasifikasi bina marga)

3. Sepeda motor (MC)

Kendaraan bermotor dengan 2 atau 3 roda (meliputi : sepeda motor dan kendaran roda 3 sesuai dengan sistem klasifikasi bina marga)

4. Kendaraan tak bermotor

Kendaraan dengan roda yang digerakkan oleh manusia (meliputi : sepeda, becak dan kereta dorong sesuai dengan klasifikasi bina marga)

\section{Kapasitas Persimpangan}

Kapasitas persimpangan merupakan arus lalu lintas maksimum yang dapat melalui suatu persimpangan pada keadaan lalu lintas awal dan keadaan lalu lintas akhir serta tanda-tanda lalu lintasnya. Arus lalu lintas maksimum dihitung untuk periode waktu 15 menit dan dinyatakan dalam kendaraan per jam. Manual Kapasitas Jalan Indonesia (1997), rumus kapasitas :

$\mathrm{C}=\mathrm{Co}^{*} \mathrm{~F}_{\mathrm{W}} * \mathrm{~F}_{\mathrm{M}} * \mathrm{~F}_{\mathrm{CS}} * \mathrm{~F}_{\mathrm{RSU}} * \mathrm{~F}_{\mathrm{LT}} * \mathrm{~F}_{\mathrm{RT}} * \mathrm{~F}_{\mathrm{MI}}$

dimana :

C : Kapasitas (smp/jam)

Co : Kapasitas dasar (smp/jam)

$\mathrm{F}_{\mathrm{W}}$ : Faktor penyesuaikan lebar masuk (m)

$\mathrm{F}_{\mathrm{M}}$ : Faktor penyesuaian jalan utama (m)

$\mathrm{F}_{\mathrm{CS}}$ : Faktor penyesuaian kota

$\mathrm{F}_{\mathrm{RSU}}$ : Faktor penyesuaian tipe lingkungan jalan, hambataan samping dan kendaraan tak bermotor

$\mathrm{F}_{\mathrm{LT}}$ : Faktor penyesuaian belok kiri

$\mathrm{F}_{\mathrm{RT}}$ : Faktor penyesuaian belok kanan

$\mathrm{F}_{\mathrm{MI}}$ : Faktor penyesuaian rasio arus jalan minor

\section{Derajat Kejenuhan}

Derajat kejenuhan didefinisikan sebagai arus maksimum yang dapat melewati garis berhenti pada suatu lengan pada kecepatan rendah dan dinyatakan dalam kendaraan per jam. Manual Kapasitas Jalan Indonesia (1997), derajat kejenuhan adalah DS, dihitung dengan menggunakan rumus sebagai berikut :

$\mathrm{DS}=\mathrm{Q}_{\mathrm{TOT}}$<smiles>[CH-]1[CH-]CC1</smiles>

dimana :

$\mathrm{Q}_{\text {тот }}$ : Arus total sesungguhnya (smp/jam)

C : Kapasitas (smp/jam)

\section{Tundaan Total Rata-Rata}

Tundaan total rata-rata seluruh persimpangan (detik/jam) dan tundaan untuk jalan persimpangan dan jalan utama didapatkan dari kurva tundaan perderajat kejenuhan yang empiris, tundaan meningkat secara berarti dengan bertambahnya derajat kejenuhan. Manual Kapasitas Jalan Indonesia, (1997), tundaan $\mathrm{D}_{\mathrm{MI}}$, dihitung dengan menggunakan rumus sebagai berikut :

$\mathrm{D}_{\text {TOT }}=2+8.7078 \mathrm{DS}$

$$
\begin{aligned}
\mathrm{D}_{\mathrm{MA}}= & \frac{1}{(0.346-0.246 \mathrm{DS})} \\
\mathrm{D}_{\mathrm{MI}}= & \frac{\left(\mathrm{Q}_{\mathrm{TOT}} \times \mathrm{D}_{\mathrm{TOT}}-\mathrm{Q}_{\mathrm{MA}} \times \mathrm{D}_{\mathrm{MA}}\right) \operatorname{detik} / \mathrm{smp}}{\mathrm{Q}_{\mathrm{MI}}}
\end{aligned}
$$

dimana :

$\mathrm{Q}_{\text {тот }}$ : Arus total (smp/jam)

$\mathrm{D}_{\text {тот }}$ : Tundaan rata-rata total (detik/smp)

$\mathrm{Q}_{\mathrm{MA}}$ : Arus total jalan utama (smp/jam)

$\mathrm{D}_{\mathrm{MA}}$ : Tundaan rata-rata jalan utama (detik/smp)

$\mathrm{Q}_{\mathrm{MI}}$ : Arus total jalan simpang (minor) (smp/jam)

\section{Peluang Antrian}

Peluang antrian QP \% diperkiraan dari peluang antrian/derajat kejenuhan yang empiris dibawah ini, Manual Kapasitas Jalan Indonesia, (1997) : 
QPatas $=47,7 \times \mathrm{DS}+24,68 \times \mathrm{DS}^{2}+56,47 \times$ $\mathrm{DS}^{3}$

QPbawah $=9,02 \times \mathrm{DS}+20,85 \times \mathrm{DS}^{2}+10,48+$ $\mathrm{DS}^{3}$

\section{METODE PENELITIAN}

Sebelum dilakukan survai lalu lintas pada persimpangan, pertama yang dilakukan adalah survai kondisi persimpangan yang meliputi geometrik persimpangan, karakteristik persimpangan dan volume lalu lintas (Munawar Ahmad, 2006).

\section{Lokasi Penelitian}

Persimpangan yang ditinjau adalah persimpangan tiga gadut, jalan raya indarungbandar buat, kota Padang. Persimpangan ini mempunyai tiga lengan. Persimpangan gadut ini dapat dijadikan objek penelitian karena :

1. Kondisi arus lalu lintas dipersimpangan ini cukup tinggi

2. Geometrik jalan yang ada sekarang ini tidak sebanding dengan volume kendaraan yang melintasi jalan tersebut

\section{Metode Survai}

Metode survai dilapangan untuk mencari data-data lapangan. Data-data lapangan yang akan diambil adalah sebagai berikut (Pedoman Pengumpulan Data Lalu Lintas, 1990) :

1. Data geometrik jalan

a. Lebar lengan simpang

Untuk mengetahui lebar lengan dapat dilakukan dengan cara mengukur lebar jalan dari tepi perkerasan kiri hingga tepi perkerasan kanan dari ketiga lengan yang ditinjau

b. Lebar lajur

Untuk mengetahui lebar lajur dapat dilakukan dengan cara mengukur lebar jalan dari tepi perkerasan kiri hingga ke garis tengah/garis pembatas lajur dari ketiga lengan yang ditinjau

c. Jumlah lajur

Jumlah lajur ditentukan dengan menghitung jumlah lajur dijalan utama dan jumlah lajur jalan persimpangan

2. Data lingkungan

a. Hambatan samping

Hambatan samping dapat dilihat dari kegiatan yang dilakukan disekitar persimpangan b. Tipe persimpangan

Tipe persimpangan dapat dilihat dengan menentukan berapa jumlah lengan dan lajur

c. Letak persimpangan

Letak persimpangan apakah terletak didaerah komersial, pemukiman atau akses terbatas

3. Data lalu lintas

a. Kendaraan ringan (LV)

b. Kendaraan berat (HV)

c. Sepeda motor (MC)

d. Kendaraan tak bermotor (UM)

\section{Metode Pengumpulan Data}

Peralatan yang digunakan untuk pengambilan data adalah sebagai berikut (Pedoman Pengumpulan Data Lalu Lintas, 1990) :

1. Enam (6) surveyor untuk mengamati arus lalu lintas yang masuk ke persimpangan

2. Formulir data

3. Alat tulis

4. Meteran

5. Kamera untuk mengambil foto situasi

6. Peralatan lain yang mendukung

\section{Waktu Penelitian}

Penelitian dilakukan melalui beberapa tahap, dimana masing-masing tahap dilakukan dengan seksama. Dalam penelitian ini, untuk dapat mengambil hasil penelitian yang akurat tentunya harus didukung dengan hasil pengamatan yang baik terhadap kondisi dilapangan yang sebenarnya. Untuk mendapatkan arus lalu lintas maksimum pada persimpangan gadut dilakukan dalam 2 (dua) hari, yaitu hari Senin dan hari Sabtu. Perhitungan jumlah kendaraan dilakukan pada jam puncak pergerakan masyarakat.

1. Jam-jam puncak tersebut adalah :
a. Jam $07.00-08.00 \mathrm{Wib}$
b. Jam $12.00-13.00 \mathrm{Wib}$
c. Jam $16.00-17.00 \mathrm{Wib}$

2. Metode pengumpulan data :

a. Enam surveyor ditempatkan pada ketiga lengan persimpangan, masing-masing 2 (dua) surveyor yang sudah dilengakapi dengan format data, alat tulis, alat hitung untuk mencatat jumlah kendaraan yang melewati persimpangan

b. Mengukur lebar ketiga lengan persimpangan 
c. Mengukur batas antrian kendaraan ketiga lengan persimpangan

d. Pencatatan jenis kendaraan dilakukan selama jam puncak

\section{HASIL DAN PEMBAHASAN}

\section{Deskripsi Data}

1. Perhitungan volume lalu lintas

2. Perhitungan kapasitas

3. Perhitungan derajat kejenuhan

4. Perhitungan tundaan total rata-rata, tundaaan rata-rata jalan utama dan tundaan rata-rata jalan persimpangan

\begin{tabular}{|c|c|c|c|c|c|c|}
\hline \multirow[t]{2}{*}{$\begin{array}{l}\text { Tipe } \\
\text { Lengan } \\
\text { Simpang }\end{array}$} & \multicolumn{2}{|c|}{$\begin{array}{l}\text { A } \\
\text { Lengan } \\
\text { Simpang Jalan } \\
\text { Raya Indarung } \\
\text { (dari Arah } \\
\text { Indarung) }\end{array}$} & \multicolumn{2}{|c|}{$\begin{array}{l}\text { B } \\
\text { Lengan } \\
\text { Simpang } \\
\text { Jalan Raya } \\
\text { Bandar Buat } \\
\text { (dari Arah } \\
\text { Bandar Buat) } \\
\end{array}$} & \multicolumn{2}{|c|}{$\begin{array}{l}\text { C } \\
\text { Lengan } \\
\text { Simpang Jalan } \\
\text { Gadut (dari } \\
\text { Arah Gadut) }\end{array}$} \\
\hline & $\begin{array}{l}\text { Belok } \\
\text { Kanan } \\
\text { (RT) }\end{array}$ & $\begin{array}{l}\text { Lurus } \\
\text { (ST) }\end{array}$ & $\begin{array}{l}\text { Belok } \\
\text { Kiri } \\
\text { (LT) } \\
\end{array}$ & $\begin{array}{l}\text { Lurus } \\
\text { (ST) }\end{array}$ & $\begin{array}{l}\text { Belok } \\
\text { Kanan } \\
\text { (RT) }\end{array}$ & $\begin{array}{l}\text { Belok } \\
\text { Kiri } \\
\text { (LT) }\end{array}$ \\
\hline LV & 382 & 405 & 350 & 497 & 490 & 429 \\
\hline $\mathrm{HV}$ & 0 & 10 & 0 & 6 & 0 & 0 \\
\hline $\mathrm{MC}$ & 620 & 592 & 587 & 600 & 525 & 574 \\
\hline UM & 0 & 0 & 0 & 0 & 0 & 0 \\
\hline Sub Total & 1002 & 1007 & 937 & 1103 & 1015 & 1003 \\
\hline Total & $\begin{array}{l}\text { Total A } \\
2009\end{array}$ & & $\begin{array}{l}\text { Total B } \\
2040\end{array}$ & & $\begin{array}{l}\text { Total C } \\
2018\end{array}$ & \\
\hline
\end{tabular}

Sumber : Hasil

Penelitian, 2017
5. Perhitungan peluang antrian

\section{Perhitungan Volume Lalu Lintas}

Perhitungan volume lalu lintas dilakukan selama 2 hari yaitu pada hari Senin (11 Desember 2017) dan hari Sabtu (16 Desember 2017).

1. Arus lalu lintas dipersimpangan tiga gadut pada hari senin tanggal 11 Desember 2017

Tabel-1. Volume lalu lintas hasil survai jam $07.00-08.00 \mathrm{Wib}$

Tabel-2. Volume lalu lintas hasil survai jam 12.00 - 13.00 Wib

\begin{tabular}{|c|c|c|c|c|c|c|}
\hline \multirow[t]{2}{*}{$\begin{array}{l}\text { Tipe } \\
\text { Lengan } \\
\text { Simpang }\end{array}$} & \multicolumn{2}{|c|}{$\begin{array}{l}\text { A } \\
\text { Lengan } \\
\text { Simpang Jalan } \\
\text { Raya Indarung } \\
\text { (dari Arah } \\
\text { Indarung) }\end{array}$} & \multicolumn{2}{|c|}{$\begin{array}{l}\text { B } \\
\text { Lengan } \\
\text { Simpang } \\
\text { Jalan Raya } \\
\text { Bandar Buat } \\
\text { (dari Arah } \\
\text { Bandar Buat) }\end{array}$} & \multicolumn{2}{|c|}{$\begin{array}{l}\text { C } \\
\text { Lengan } \\
\text { Simpang Jalan } \\
\text { Gadut (dari } \\
\text { Arah Gadut) }\end{array}$} \\
\hline & $\begin{array}{l}\text { Belok } \\
\text { Kanan } \\
\text { (RT) }\end{array}$ & $\begin{array}{l}\text { Lurus } \\
\text { (ST) }\end{array}$ & $\begin{array}{l}\text { Belok } \\
\text { Kiri } \\
\text { (LT) }\end{array}$ & $\begin{array}{l}\text { Lurus } \\
\text { (ST) }\end{array}$ & $\begin{array}{l}\text { Belok } \\
\text { Kanan } \\
\text { (RT) }\end{array}$ & $\begin{array}{l}\text { Belok } \\
\text { Kiri } \\
\text { (LT) }\end{array}$ \\
\hline
\end{tabular}




\begin{tabular}{lllllll}
\hline LV & 290 & 420 & 467 & 492 & 401 & 356 \\
\hline HV & 0 & 100 & 0 & 110 & 1 & 2 \\
\hline MC & 621 & 602 & 697 & 699 & 680 & 597 \\
\hline UM & 0 & 0 & 0 & 0 & 0 & 0 \\
\hline $\begin{array}{l}\text { Sub } \\
\text { Total }\end{array}$ & 911 & 1122 & 1164 & 1301 & 1082 & 955 \\
\hline Total & $\begin{array}{l}\text { Total A }= \\
2033\end{array}$ & $\begin{array}{l}\text { Total B }= \\
2465\end{array}$ & $\begin{array}{l}\text { Total C }= \\
2037\end{array}$ \\
\hline
\end{tabular}

Sumber : Hasil Penelitian, 2017

Tabel-3. Volume lalu lintas hasil survai jam 16.00-17.00 Wib

\begin{tabular}{|c|c|c|c|c|c|c|}
\hline \multirow[t]{2}{*}{$\begin{array}{l}\text { Tipe } \\
\text { Lengan } \\
\text { Simpang }\end{array}$} & \multicolumn{2}{|c|}{$\begin{array}{l}\text { A } \\
\text { Lengan } \\
\text { Simpang Jalan } \\
\text { Raya Indarung } \\
\text { (dari Arah } \\
\text { Indarung) }\end{array}$} & \multicolumn{2}{|c|}{$\begin{array}{l}\text { B } \\
\text { Lengan } \\
\text { Simpang } \\
\text { Jalan Raya } \\
\text { Bandar Buat } \\
\text { (dari Arah } \\
\text { Bandar Buat) }\end{array}$} & \multicolumn{2}{|c|}{$\begin{array}{l}\text { C } \\
\text { Lengan } \\
\text { Simpang Jalan } \\
\text { Gadut (dari } \\
\text { Arah Gadut) }\end{array}$} \\
\hline & $\begin{array}{l}\text { Belok } \\
\text { Kanan } \\
(\mathrm{RT}) \\
\end{array}$ & $\begin{array}{l}\text { Lurus } \\
\text { (ST) }\end{array}$ & $\begin{array}{l}\text { Belok } \\
\text { Kiri } \\
(\mathrm{LT}) \\
\end{array}$ & $\begin{array}{l}\text { Lurus } \\
\text { (ST) }\end{array}$ & $\begin{array}{l}\text { Belok } \\
\text { Kanan } \\
(\mathrm{RT}) \\
\end{array}$ & $\begin{array}{l}\text { Belok } \\
\text { Kiri } \\
\text { (LT) }\end{array}$ \\
\hline LV & 406 & 540 & 410 & 425 & 421 & 320 \\
\hline HV & 0 & 50 & 0 & 115 & 5 & 2 \\
\hline $\mathrm{MC}$ & 625 & 700 & 687 & 799 & 680 & 610 \\
\hline UM & 0 & 0 & 0 & 0 & 0 & 0 \\
\hline $\begin{array}{l}\text { Sub } \\
\text { Total }\end{array}$ & 1031 & 1290 & 1097 & 1339 & 1106 & 932 \\
\hline Total & $\begin{array}{l}\text { Total } A \\
2321\end{array}$ & & $\begin{array}{l}\text { Total } \\
2436\end{array}$ & $=$ & $\begin{array}{l}\text { Total } \\
2038\end{array}$ & \\
\hline
\end{tabular}

Sumber : Hasil Penelitian, 2017

2. Arus lalu lintas dipersimpangan tiga gadut pada hari sabtu tanggal 16 Desember 2017

Tabel-4. Volume lalu lintas hasil survai jam 07.00-08.00 Wib

\begin{tabular}{|c|c|c|c|c|c|c|}
\hline \multirow[t]{2}{*}{$\begin{array}{l}\text { Tipe } \\
\text { Lengan } \\
\text { Simpang }\end{array}$} & \multicolumn{2}{|c|}{$\begin{array}{l}\text { A } \\
\text { Lengan } \\
\text { Simpang Jalan } \\
\text { Raya Indarung } \\
\text { (dari Arah } \\
\text { Indarung) }\end{array}$} & \multicolumn{2}{|c|}{$\begin{array}{l}\text { B } \\
\text { Lengan } \\
\text { Simpang } \\
\text { Jalan Raya } \\
\text { Bandar Buat } \\
\text { (dari Arah } \\
\text { Bandar Buat) }\end{array}$} & \multicolumn{2}{|c|}{$\begin{array}{l}\text { C } \\
\text { Lengan } \\
\text { Simpang Jalan } \\
\text { Gadut (dari } \\
\text { Arah Gadut) }\end{array}$} \\
\hline & $\begin{array}{l}\text { Belok } \\
\text { Kanan } \\
\text { (RT) }\end{array}$ & $\begin{array}{l}\text { Lurus } \\
\text { (ST) }\end{array}$ & $\begin{array}{l}\text { Belok } \\
\text { Kiri } \\
\text { (LT) }\end{array}$ & $\begin{array}{l}\text { Lurus } \\
\text { (ST) }\end{array}$ & $\begin{array}{l}\text { Belok } \\
\text { Kanan } \\
\text { (RT) }\end{array}$ & $\begin{array}{l}\text { Belok } \\
\text { Kiri } \\
\text { (LT) }\end{array}$ \\
\hline LV & 320 & 76 & 300 & 492 & 392 & 356 \\
\hline
\end{tabular}




\begin{tabular}{lllllll}
\hline HV & 0 & 20 & 1 & 32 & 0 & 1 \\
\hline MC & 530 & 615 & 584 & 677 & 695 & 501 \\
\hline UM & 0 & 0 & 0 & 0 & 0 & 0 \\
\hline $\begin{array}{l}\text { Sub } \\
\text { Total }\end{array}$ & 850 & 1111 & 885 & 1201 & 1087 & 858 \\
\hline Total & $\begin{array}{l}\text { Total A }= \\
1961\end{array}$ & $\begin{array}{l}\text { Total B }= \\
2086\end{array}$ & \multicolumn{2}{l}{$\begin{array}{l}\text { Total C }= \\
1945\end{array}$} \\
\end{tabular}

Sumber : Hasil Penelitian, 2017

Tabel-5. Volume lalu lintas hasil survai jam $12.00-13.00 \mathrm{Wib}$

\begin{tabular}{|c|c|c|c|c|c|c|}
\hline \multirow[t]{2}{*}{$\begin{array}{l}\text { Tipe } \\
\text { Lengan } \\
\text { Simpang }\end{array}$} & \multicolumn{2}{|c|}{$\begin{array}{l}\text { A } \\
\text { Lengan } \\
\text { Simpang Jalan } \\
\text { Raya Indarung } \\
\text { (dari Arah } \\
\text { Indarung) }\end{array}$} & \multicolumn{2}{|c|}{$\begin{array}{l}\text { B } \\
\text { Lengan } \\
\text { Simpang } \\
\text { Jalan Raya } \\
\text { Bandar Buat } \\
\text { (dari Arah } \\
\text { Bandar Buat) }\end{array}$} & \multicolumn{2}{|c|}{$\begin{array}{l}\text { C } \\
\text { Lengan } \\
\text { Simpang Jalan } \\
\text { Gadut (dari } \\
\text { Arah Gadut) }\end{array}$} \\
\hline & $\begin{array}{l}\text { Belok } \\
\text { Kanan } \\
(\mathrm{RT})\end{array}$ & $\begin{array}{l}\text { Lurus } \\
\text { (ST) }\end{array}$ & $\begin{array}{l}\text { Belok } \\
\text { Kiri } \\
(\mathrm{LT}) \\
\end{array}$ & $\begin{array}{l}\text { Lurus } \\
\text { (ST) }\end{array}$ & $\begin{array}{l}\text { Belok } \\
\text { Kanan } \\
(\mathrm{RT}) \\
\end{array}$ & $\begin{array}{l}\text { Belok } \\
\text { Kiri } \\
\text { (LT) } \\
\end{array}$ \\
\hline LV & 459 & 517 & 389 & 567 & 346 & 356 \\
\hline HV & 2 & 59 & 0 & 68 & 1 & 0 \\
\hline $\mathrm{MC}$ & 697 & 721 & 595 & 374 & 600 & 571 \\
\hline UM & 0 & 0 & 0 & 0 & 0 & 0 \\
\hline $\begin{array}{l}\text { Sub } \\
\text { Total }\end{array}$ & 1158 & 1297 & 984 & 1369 & 946 & 927 \\
\hline Total & $\begin{array}{l}\text { Total A } \\
2455\end{array}$ & $=$ & $\begin{array}{l}\text { Total } \\
2353\end{array}$ & & $\begin{array}{l}\text { Total } \\
1873\end{array}$ & \\
\hline
\end{tabular}

Sumber : Hasil Penelitian, 2017

Tabel-6. Volume lalu lintas hasil survai jam $16.00-17.00 \mathrm{Wib}$

\begin{tabular}{|c|c|c|c|c|c|c|}
\hline \multirow[t]{2}{*}{$\begin{array}{l}\text { Tipe } \\
\text { Lengan } \\
\text { Simpang }\end{array}$} & \multicolumn{2}{|c|}{$\begin{array}{l}\text { A } \\
\text { Lengan } \\
\text { Simpang Jalan } \\
\text { Raya Indarung } \\
\text { (dari Arah } \\
\text { Indarung) }\end{array}$} & \multicolumn{2}{|c|}{$\begin{array}{l}\text { B } \\
\text { Lengan } \\
\text { Simpang } \\
\text { Jalan Raya } \\
\text { Bandar Buat } \\
\text { (dari Arah } \\
\text { Bandar Buat) } \\
\end{array}$} & \multicolumn{2}{|c|}{$\begin{array}{l}\text { C } \\
\text { Lengan } \\
\text { Simpang Jalan } \\
\text { Gadut (dari } \\
\text { Arah Gadut) }\end{array}$} \\
\hline & $\begin{array}{l}\text { Belok } \\
\text { Kanan } \\
\text { (RT) }\end{array}$ & $\begin{array}{l}\text { Lurus } \\
\text { (ST) }\end{array}$ & $\begin{array}{l}\text { Belok } \\
\text { Kiri } \\
\text { (LT) }\end{array}$ & $\begin{array}{l}\text { Lurus } \\
\text { (ST) }\end{array}$ & $\begin{array}{l}\text { Belok } \\
\text { Kanan } \\
\text { (RT) }\end{array}$ & $\begin{array}{l}\text { Belok } \\
\text { Kiri } \\
\text { (LT) }\end{array}$ \\
\hline LV & 331 & 462 & 357 & 491 & 301 & 293 \\
\hline HV & 1 & 72 & 0 & 69 & 0 & 2 \\
\hline $\mathrm{MC}$ & 597 & 751 & 687 & 780 & 721 & 471 \\
\hline
\end{tabular}




\begin{tabular}{|c|c|c|c|c|c|c|}
\hline UM & 0 & 0 & 0 & 2 & 0 & 0 \\
\hline $\begin{array}{l}\text { Sub } \\
\text { Total }\end{array}$ & 929 & 1285 & 1044 & 1340 & 1022 & 766 \\
\hline Total & $\begin{array}{l}\text { Total } \\
2214\end{array}$ & $=$ & $\begin{array}{l}\text { Total } \\
2384\end{array}$ & $=$ & $\begin{array}{l}\text { Total } \\
1788\end{array}$ & $=$ \\
\hline
\end{tabular}

Sumber : Hasil Penelitian, 2017

\section{Perhitungan Kapasitas}

Menentukan nilai rumusan kapasitas hari senin tanggal 11 Desember 2017 jam 07.00 $08.00 \mathrm{Wib}$ :

1. Kapasitas dasar (Co)

Untuk menentukan Co persimpangan tiga gadut, dilihat dari jumlah lengan persimpangan dan jumlah lajur, maka persimpangan tersebut digolongkan pada tipe 324 dengan kapasitas awal (Co) adalah $3200 \mathrm{smp} / \mathrm{jam}$.

2. Faktor penyesuaian lebar pendekat $(\mathrm{Fw})$

Koreksi lebar masuk pada persimpangan tiga gadut dicari dengan menggunakan data dilapangan yaitu lebar dari masing-masing lengan persimpangan, kemudian data tersebut digunakan untuk mencari nilai rata-rata lengan simpang $\left(\mathrm{W}_{\mathrm{E}}\right)$ :

$$
\begin{aligned}
& \mathrm{W}_{\mathrm{E}}=\frac{\mathrm{A} / 2+\mathrm{B} / 2+\mathrm{C} / 2}{3} \\
& \mathrm{~W}_{\mathrm{E}}=\frac{9 / 2+9 / 2+8 / 2}{3}
\end{aligned}
$$

$\mathrm{W}_{\mathrm{E}}=4,3 \mathrm{~m}$

Untuk mencari nilai $\mathrm{Fw}$ disesuaikan dengan tipe persimpangan, dimana tipe persimpangan tiga gadut adalah tipe 324 .

$\mathrm{FW}=0,62+0,0646 \times \mathrm{W}_{\mathrm{E}}$

$\mathrm{FW}_{\mathrm{W}}=0,62+0,0646 \times 4,3$

$\mathrm{FW}_{\mathrm{W}}=0,89 \mathrm{~m}$

3. Faktor penyesuaian median jalan utama (jalan raya indarung dan jalan raya bandar buat) $\left(\mathrm{F}_{\mathrm{M}}\right)$

Untuk mendapatkan nilai dari faktor koreksi pada median jalan utama persimpangan tiga gadut, maka diambil faktor koreksi median $\left(\mathrm{F}_{\mathrm{M}}\right)=1,05$.

4. Faktor penyesuaian ukuran kota $\left(\mathrm{F}_{\mathrm{CS}}\right)$

Untuk mendapatkan nilai dari faktor penyesuaian ukuran kota, jumlah penduduk kota padang diperkirakan 876.678 jiwa (BPS kota Padang, 2016), didapatkan faktor penyesuaian ukuran kota $\left(\mathrm{F}_{\mathrm{CS}}\right)=0,94$.
5. Faktor penyesuaian tipe lingkungan jalan hambatan dan kendaraan tak bermotor $\left(\mathrm{F}_{\mathrm{RSU}}\right)$

Untuk menghitung faktor penyesuaian hambatan samping dan kendaraan tak bermotor, yang perlu ditentukan agar didapatkan nilai $\mathrm{F}_{\mathrm{RSU}}$ yaitu sebagai berikut :

a. Tentukan rasio kendaraan tak bermotor

Untuk mendapatkan nilai rasio kendaraan tak bermotor digunakan nilai $\mathrm{P}_{\mathrm{UM}}$. Dimana $\mathrm{P}_{\mathrm{UM}}$ adalah jumlah kendaraan tak bermotor dibagi dengan jumlah kendaraan bermotor.

$\mathrm{P}_{\mathrm{UM}}=\frac{\mathrm{Q}_{\mathrm{UM}}}{\mathrm{Q}_{\mathrm{TOT}}}$

$\mathrm{P}_{\mathrm{UM}}=0$

$$
\overline{4322,8}
$$

$\mathrm{P}_{\mathrm{UM}}=0$

Nilai faktor kendaraan tak bermotor $\left(\mathrm{F}_{\mathrm{RSU}}\right)$ dipersimpangan tiga gadut adalah 0,94.

6. Faktor penyesuaian belok kiri $\left(\mathrm{F}_{\mathrm{LT}}\right)$

Untuk mendapatkan nilai dari faktor penyesuaian belok kiri, tentukan terlebih dahulu nilai LT \% yaitu jumlah kendaraan yang belok kiri dalam $\%$.

$\mathrm{P}_{\mathrm{LT}} \%=\mathrm{Q}_{\mathrm{LT}} \mathrm{x} 100$

$\mathrm{P}_{\mathrm{LT}} \%=\frac{1359,5}{4322,8} \times 100$

$\mathrm{P}_{\mathrm{LT}} \%=31,44$

Maka nilai $\mathrm{F}_{\mathrm{LT}}$ :

$\mathrm{F}_{\mathrm{LT}}=0,84+0,0161 \times \mathrm{P}_{\mathrm{LT}} \%$

$\mathrm{F}_{\mathrm{LT}}=0,84+(0,0161 \times 31,44)$

$\mathrm{F}_{\mathrm{LT}}=1,34$

7. Faktor penyesuaian belok kanan $\left(\mathrm{F}_{\mathrm{RT}}\right)$

Untuk mendapatkan nilai dari faktor penyesuaian belok kanan. Tentukan terlebih dahulu nilai RT \% yaitu jumlah kendaraan yang belok kanan dalam $\%$.

$\mathrm{P}_{\mathrm{RT}} \%=\underline{\mathrm{QRT}_{\mathrm{RT}}} \times 100$

$\mathrm{P}_{\mathrm{RT}} \%=1444,5 \times 100$

$\mathrm{P}_{\mathrm{RT}} \%=33,41$

Maka nilai $\mathrm{F}_{\mathrm{RT}}$ :

$\mathrm{F}_{\mathrm{RT}}=1,09-0,0092 \times \mathrm{P}_{\mathrm{RT}} \%$

$\mathrm{F}_{\mathrm{RT}}=1,09-(0,0092 \times 33,41)$ 
$\mathrm{F}_{\mathrm{RT}}=0,78$

8. Faktor penyesuaian rasio arus jalan simpang

$\left(\mathrm{F}_{\mathrm{MI}}\right)$

Untuk mendapatkan nilai dari faktor penyesuaian rasio arus jalan persimpangan, tentukan terlebih dahulu tipe persimpangan dan rasio arus jalan persimpangan $\left(\mathrm{P}_{\mathrm{MI}}\right)$ yaitu :

$\mathrm{P}_{\mathrm{MI}}=\frac{\mathrm{Q}_{\mathrm{MI}}}{\mathrm{Q}_{\mathrm{TOT}}}$

$\mathrm{P}_{\mathrm{MI}}=\frac{1468,5}{4322,8}$

$\mathrm{P}_{\mathrm{MI}}=0,34$

Maka nilai $\mathrm{F}_{\mathrm{MI}}$ :

$\mathrm{F}_{\mathrm{MI}}=16,6 \times \mathrm{P}_{\mathrm{MI}}{ }^{4}-33,3 \times \mathrm{P}_{\mathrm{MI}}^{3}+25,3 \times \mathrm{P}_{\mathrm{MI}}^{2}-$ $8,6 \times \mathrm{P}_{\mathrm{MI}}+1,95$

$\mathrm{F}_{\mathrm{MI}}=16,6 \times 0,34^{4}-33,3 \times 0,34^{3}+25,3 \times 0,34^{2}$ $-8,6 \times 0,34+1,95$

$\mathrm{F}_{\mathrm{MI}}=(0,22)-(0,13)+(2,92)-(2,9)+(1,95)$

$\mathrm{F}_{\mathrm{MI}}=2,06$

Tabel-7. Hasil perhitungan masing-masing notasi rumusan kapasitas

\begin{tabular}{cccccccc}
\hline $\mathbf{C}_{\mathbf{O}}$ & $\mathbf{F}_{\mathbf{W}}$ & $\mathbf{F}_{\mathbf{M}}$ & $\mathbf{F}_{\mathbf{C S}}$ & $\mathbf{F}_{\mathbf{R S U}}$ & $\mathbf{F}_{\mathbf{L T}}$ & $\mathbf{F}_{\mathbf{R T}}$ & $\mathbf{F}_{\mathbf{M I}}$ \\
\hline 3200 & 0,89 & 1,05 & 0,94 & 0,94 & 1,34 & 0,78 & 2,06 \\
\hline
\end{tabular}

Sumber : Hasil Perhitungan, 2017

Setelah didapatkan nilai dari masing-masing notasi, maka nilai kapasitas untuk persimpangan tiga gadut adalah :

$\mathrm{C}=\mathrm{Co} * \mathrm{~F}_{\mathrm{W}} * \mathrm{~F}_{\mathrm{M}} * \mathrm{~F}_{\mathrm{CS}} * \mathrm{~F}_{\mathrm{RSU}} * \mathrm{~F}_{\mathrm{LT}} * \mathrm{~F}_{\mathrm{RT}} * \mathrm{~F}_{\mathrm{MI}}$

$\mathrm{C}=3200 \times 0,89 \times 1,05 \times 0,94 \times 0,94 \times 1,34 \times$

$0,78 \times 2,06$

$\mathrm{C}=5689,2 \mathrm{smp} / \mathrm{jam}$

\section{Perhitungan Derajat Kejenuhan}

Tingkat derajat kejenuhan pada persimpangan tiga gadut dapat ditentukan setelah dilakukan pengambilan data volume lalu lintas dan data geometrik dari persimpangan tersebut. Kemudian dilakukan analisis data :

$\mathrm{DS}=\mathrm{Q}_{\mathrm{TOT}}$
$\mathrm{C}$

$\mathrm{DS}=4322,8$

5689,2

$\mathrm{DS}=0,76 \mathrm{smp} / \mathrm{jam}$

\section{Perhitungan Tundaan Total Rata-Rata}

Tundaan terhadap persimpangan dapat dihitung dengan menggunakan rumus :

1. Tundaan total (D) dihitung sesuai dengan rumus :
$\mathrm{D}_{\mathrm{TOT}}=2+8,7078 \times \mathrm{DS}$
$\mathrm{D}_{\text {TOT }}=2+8,7078 \times 0,76$
$\mathrm{D}=8,61 \mathrm{detikt} / \mathrm{smp}$

2. Tundaan pada jalan minor $\left(\mathrm{D}_{\mathrm{MA}}\right)$ dihitung sesuai dengan rumus :

$$
\begin{aligned}
& \mathrm{D}_{\mathrm{MA}}=\frac{1}{(0,346-0,246 \times \mathrm{DS})} \\
& \mathrm{D}_{\mathrm{MA}}=\frac{1}{(0,346-0,246 \times 0,76)} \\
& \mathrm{D}_{\mathrm{MA}}=6,28 \mathrm{detik} / \mathrm{smp}
\end{aligned}
$$

3. Tundaan pada jalan mayor $\left(\mathrm{D}_{\mathrm{MI}}\right)$ dihitung sesuai dengan rumus :

$$
\begin{aligned}
\mathrm{D}_{\mathrm{MI}} & =\frac{\left(\mathrm{Q}_{\mathrm{TOT}} \times \mathrm{D}-\mathrm{Q}_{\mathrm{MA}} \times \mathrm{D}_{\mathrm{MA}}\right)}{\left(\mathrm{Q}_{\mathrm{MI}} \operatorname{detik} / \mathrm{smp}\right)} \\
\mathrm{D}_{\mathrm{MI}} & =\frac{(4322,8 \times 8,61-2854,3 \times 6,28)}{(1468,5 \mathrm{detik} / \mathrm{smp})} \\
\mathrm{D}_{\mathrm{MI}} & =13,13 \mathrm{detik} / \mathrm{smp}
\end{aligned}
$$

\section{Perhitungan Peluang Antrian}

Untuk mencari nilai peluang antrian (QP \%) dapat dihitung dengan menggunakan nilai QP atas dan QP bawah yaitu :

$\mathrm{QP}_{\text {atas }}=47,7 \times \mathrm{DS}+24,68 \times \mathrm{DS}^{2}+56,47 \times$ $\mathrm{DS}^{3}$

$\mathrm{QP}_{\text {atas }}=47,7 \times 0,76+24,68 \times 0,76^{2}+56,47 \times$ $0,76^{3}$

$\mathrm{QP}_{\text {atas }}=75,29 \%$

$\mathrm{QP}_{\text {bawah }}=9,02 \times \mathrm{DS}+20,85 \times \mathrm{DS}^{2}+10,85 \times$

$\mathrm{DS}^{3}$

$\mathrm{QP}_{\text {bawah }}=9,02 \times 0,76+20,85 \times 0,76^{2}+10,85 \times$ $0,76^{3}$

$\mathrm{QP}_{\text {bawah }}=23,61 \%$ 
Tabel-8. Hasil perhitungan pada hari Senin tanggal 11 desember 2017

\begin{tabular}{lcccc}
\hline \multirow{2}{*}{ Uraian } & Satuan & \multicolumn{3}{c}{ Jam Puncak } \\
\cline { 3 - 5 } & $\mathbf{0 7 . 0 0} 08.00$ & $\mathbf{1 2 . 0 0 ~ 1 3 . 0 0}$ & $\mathbf{1 6 . 0 0 1 7 . 0 0}$ \\
\hline Kapasitas (C) & smp/jam & 5689,2 & 5109,9 & 4671,6 \\
\hline $\begin{array}{l}\text { Derajat } \\
\text { kejenuhan (DS) }\end{array}$ & smp/jam & 0,76 & 0,9 & 1 \\
\hline $\begin{array}{l}\text { Tundaan total } \\
\text { rata-rata (D) }\end{array}$ & $\begin{array}{c}\text { detik/sm } \\
\mathrm{p}\end{array}$ & 8,61 & 9,63 & 10,7 \\
\hline $\begin{array}{l}\text { Tundaan rata-rata } \\
\text { jalan minor } \\
\left(\mathrm{D}_{\mathrm{MA}}\right)\end{array}$ & $\begin{array}{c}\text { detik/sm } \\
\mathrm{p}\end{array}$ & 6,28 & 8 & 10 \\
\hline $\begin{array}{l}\text { Tundaan rata-rata } \\
\text { jalan mayor (D }\end{array}$ & $\begin{array}{c}\text { detik/sm } \\
\mathrm{p}\end{array}$ & 13,13 & 13,41 & 12,34 \\
\hline $\begin{array}{l}\text { Peluang antrian } \\
\text { atas }(\mathrm{QP}\end{array}$ & $\%$ & 75,29 & 103,9 & 128,8 \\
\hline $\begin{array}{l}\text { Peluang antrian } \\
\text { bawah }\left(\mathrm{QP}_{\text {bawah }}\right)\end{array}$ & $\%$ & 23,61 & 32,5 & 40,35 \\
\hline
\end{tabular}

Sumber : Hasil Perhitungan, 2017

Tabel-9. Hasil perhitungan pada hari Sabtu tanggal 16 desember 2017

\begin{tabular}{|c|c|c|c|c|}
\hline \multirow{2}{*}{ Uraian } & \multirow{2}{*}{ Satuan } & \multicolumn{3}{|c|}{ Jam Puncak } \\
\hline & & 07.0008 .00 & 12.0013 .00 & 16.0017 .00 \\
\hline Kapasitas (C) & smp/jam & 5496,1 & 4788,5 & 3706,3 \\
\hline $\begin{array}{l}\text { Derajat } \\
\text { kejenuhan (DS) }\end{array}$ & smp/jam & 0,77 & 0,9 & 1,1 \\
\hline $\begin{array}{l}\text { Tundaan total } \\
\text { rata-rata (D) }\end{array}$ & $\begin{array}{c}\operatorname{detik} / \mathrm{sm} \\
\mathrm{p}\end{array}$ & 8,7 & 9,83 & 11,57 \\
\hline $\begin{array}{l}\text { Tundaan rata-rata } \\
\text { jalan minor } \\
\left(D_{\mathrm{MA}}\right)\end{array}$ & $\begin{array}{c}\mathrm{detik} / \mathrm{sm} \\
\mathrm{p}\end{array}$ & 6,38 & 8 & 13,26 \\
\hline $\begin{array}{l}\text { Tundaan rata-rata } \\
\text { jalan mayor }\left(\mathrm{D}_{\mathrm{MI}}\right)\end{array}$ & $\begin{array}{c}\text { detik/sm } \\
\text { p }\end{array}$ & 13,63 & 14,76 & 6,98 \\
\hline $\begin{array}{l}\text { Peluang antrian } \\
\text { atas }\left(\mathrm{QP}_{\text {atas }}\right)\end{array}$ & $\%$ & 77,13 & 104 & 157,4 \\
\hline $\begin{array}{l}\text { Peluang antrian } \\
\text { bawah }\left(\mathrm{QP}_{\text {bawah }}\right)\end{array}$ & $\%$ & 24 & 32,6 & 49,06 \\
\hline
\end{tabular}

Sumber : Hasil Perhitungan, 2017

\section{PENUTUP}

\section{Simpulan}

Dari hasil data lingkungan bahwa faktor dari hambatan samping untuk persimpangan tiga gadut adalah kriteria sedang. Hal ini berarti bahwa pengaruh dari hambatan samping untuk persimpangan tiga gadut masih belum berpengaruh. Nilai Kapasitas (C) dipersimpangan tiga gadut pada perhitungan ini yang terkecil adalah $3706,3 \mathrm{smp} / \mathrm{jam}$, sehingga nilai derajat kejenuhan adalah sebesar 1,1 smp/jam. Nilai ini sudah melewati batas nilai yang diijiinkan Manual Kapasitas Jalan
Indonesia yaitu sebesar $0,8-0,9(1,1>0,9)$ dan hal ini disimpulkan bahwa arus lalu lintas jenuh dipersimpangan tiga gadut. Nilai peluang antrian pada perhitungan ini yang terbesar berkisar antara 128,8 \% - 157,4 \% dengan tundaan total rata-rata terbesar adalah 11,57 detik/smp. Hal ini disimpulkan bahwa peluang antrian pada persimpangan ini sangat besar, sehingga bisa menyebabkan kemacetan.

\section{Saran}

Menambah rambu lalu lintas seperti rambu dilarang berhenti disepanjang daerah
210
Fakultas Teknik UMSB
ISSN 2599-2081
EISSN 2599-2090 
persimpangan. Melakukan sosialisasi dari dinas perhubungan kepada masyarakat untuk lebih disiplin dalam mentaati peraturan lalu lintas dan jika perlu memberlakukan semacam sanksi untuk pengemudi yang melakukan pelanggaran.

\section{DAFTAR PUSTAKA}

Anisa., 2009, Analisis Tingkat Kinerja Persimpangan Bersinyal Jalan Khatib Sulaiman - Jalan Rasuna Said - Jalan Raden Saleh - Jalan K.H. Ahmad Dahlan, Padang : Universitas Bung Hatta.

Departemen Pekerjaan Umum Direktorat Bina Marga., 1997, Manual Kapasitas Jalan Indonesia (MKJI), Jakarta : PT. Bina Karya.

Direktorat Bina Sistem Lalu Lintas dan Angkutan Kota, Direktorat Jenderal Perhubungan Darat., 1990, Pedoman Pengumpulan Data Lalu Lintas, Jakarta.

Hobbs, F.D., 1995, Perencanaan Dan Teknik Lalu Lintas Edisi Kedua, Yogyakarta : Gadjah Mada University Press.

Khisty, C, Jotin dan Lall, B, Kent., 2005, Dasar-Dasar Rekayasa Transportasi, Edisi ketiga, Jilid 1, Jakarta : Penerbit Erlangga.

Morlok, E.K., 1991, Pengantar Teknik dan Perencanaan Transportasi. Terjemahan Johan K. Hainim. Erlangga, Jakarta.

Munawar Ahmad., 2006, Manajemen Lalu Lintas Perkotaan, BETA OFFSET, Yogyakarta.

Oglesby, Clarkson H., 1995, Teknik Jalan Raya Edisi Keempat, Jakarta : Erlangga.

Sukirman, Silvia., 1994, Dasar-dasar Perencanaan Geometrik Jalan Raya, Bandung : Nova.

Tamin, O.Z., 2000, Perencanaan dan Pemodelan Transportasi, Edisi Kedua. Penerbit ITB Bandung. 